\title{
THE INFLUENCE OF CHANGES IN ORBITAL PARAMETERS OVER SOUTH AMERICAN CLIMATE USING THE CPTEC AGCM: SIMULATION OF CLIMATE DURING THE MID HOLOCENE
}

\author{
Maria Luciene Dias de Melo ${ }^{1 *}$, José Antonio Marengo $^{1^{2 * * *}}$ \\ $\left({ }^{1,2}\right.$ Centro de Previsão de Tempo e Estudos Climáticos / Instituto Nacional de Pesquisas \\ Espaciais - CPTEC/INPE) \\ Rodovia Presidente Dutra - 40 km, Cachoeira Paulista - São Paulo, Brazil.
}

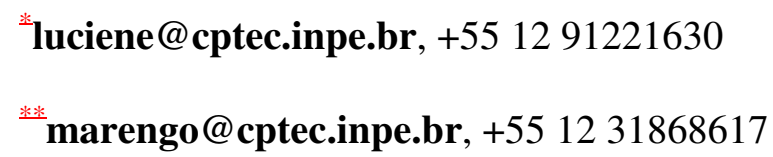

Abstract

Climate change has been analyzed for Mid Holocene (MH) over South America (SA). Simulations have been performed through modification of the orbital parameters and the $\mathrm{CO}_{2}$ concentration within the CPTEC T062L28 atmospheric general circulation models (AGCM) typical of the mid Holocene, 6000 years BP. The results were compared to previous simulations performed by various climate centers of the world and to paleoclimate indications in order to understand how the AGCM responds to climate changes and to evaluate the differences of the present climate (PC) and MH. In general it is observed a wetter behavior in northeastern SA during the $\mathrm{MH}$, except in austral autumn where there is a northward shift of the Intertropical Convergence Zone (ITCZ). On central and southeastern SA the simulations show a reduction of precipitation. A cooling signal was verified during the $\mathrm{MH}$ simulation, in accordance with paleoclimate evidences. An increase of the intensity of the mean low-level flux was verified over the continent due to a decrease of the seasonal variation of insolation 
in the southern hemisphere. This has an important impact over the transport of moisture from Amazon to the Southeastern South America, and consequently over the South America Convergence Zone (SACZ) formation. It was also verified an increase of the intensity of the northerly circulation east of Andes during the $\mathrm{MH}$ in summer, similar to present climate winter circulation

Key words: Mid Holocene, South America, CPTEC AGCM, paleoclimate, orbital parameter, paleoclimate record

\section{INTRODUCTION}

O clima de 6000 anos atrás, Mid Holocene $(\mathrm{MH})$, representa um bom teste para avaliar o desempenho dos AGCM, principalmente, por ser um período marcado por uma mudança climática natural, para o qual se conhece a forçante que é a mudança dos parâmetros orbitais, due mean sea surface temperature (SST) characteristics similar to the present; e, devido à existência de indicadores paleoclimáticos referentes a esse período. The indicators are useful to detect changes in the climate regimes in the past and to understand the functioning of the climate system. In addition paleoclimate records are useful for the "validation" of the reconstructions of the past climate through models.

Paleoclimatic indicators suggest that significant changes in the solar forcing during the Holocene led to expressive changes on the climate resulting in changes in temperature, rain, sea level height and circulation. These studies revealed a drier behavior during the MH over both the Amazon region (Turcq et al., 1998; Behling et al., 2000; Turcq et al., 2002), south and southeast Brazil (Behling, 2001; Turcq et al., 2002). Embora estudos palinológicos sobre o Vale do Paraíba do Sul (Garcial et al., 2004) e região sul do Rio de Janeiro (Coelho et al., 2002) sugiram que no MH essas regiões experimentaram clima mais úmido. Sifeddine et al. (2003) analyzing lake data from north of Northeast Brazil $\left(2.96^{\circ} \mathrm{S}\right.$ and $\left.43.41^{\circ} \mathrm{W}\right)$ verified a lowering of the level of the lake, between 11,000 and 4,500 years ago, suggesting a drier period in comparison with present climate. 
These results confirm those found by Ledru et al. (2002) using pollen data. Northern South America, including Northeast Brazil exhibited a southward displacement of the ITCZ during the MH compared with present day (Mayle et al. 2000, and Haug et al. 2001). Oscillations between more humid periods and semi-arid conditions, on the northeast of Brazil were verified in MH (de Oliveira et al., 1999).

$\underline{\text { Climate models have been used to simulate markable climate episodes (Ganopolski et }}$ al., 1998), or the climate evolution during abrupt climate events (Manabe and Stouffer, 1997) to help understand the past climate change mechanisms. The models allow for the establishment of a cause-effect association that could have happened in the past. Also $\underline{\text { they help to fill the vacuum between at regional levels and to reconstruct the global }}$ paleoclimate because paleoclimatic indicators are very sparse over time and space. A quantitative understanding of such mechanisms is perhaps the best way of learning about the past or the future climate.

There are evidences of a positive climate feedback in the response of climate to changes $\underline{\text { in orbital parameters. Comparisons between models and between models and }}$ paleoclimate indicators data have been performed by the Paleoclimate Modelling Intercomparison Project (PMIP) (Jossaume and Taylor, 1995). In PMIP all the models have changed the orbital parameters and reduced the carbon dioxide $\left(\mathrm{CO}_{2}\right)$ concentration to $280 \mathrm{ppm}$. The SST is assumed as similar to present climate values, that is, a pre-industrial atmosphere (Valdes, 2000; Ruddiman and Mix, 1993; Morley and Dworetzky, 1993). Therefore only the radiation forcing is believed to have a more remarkable contribution for the different climate of this period.

The solar radiation available at the top of the atmosphere during $\mathrm{MH}$ was quite different of the present-day values, due to changes of the orbital parameters. About 6,000 years ago, during the South Hemisphere winter, the Earth was closer to the Sun (perihelion) $\underline{\text { than it is opposed exactly in the present times. As a result the insolation seasonal cycle }}$ was modified. Thus, during MH the peak of insolation in the tropics occurred in August 
whereas the minimum occurred in February. In South Hemisphere this change desintensificou the seasonal cycle of the insolation (Liu et al., 2004). The change in the insolation is not exactly symmetric about the equator, due to both the inclination of the Earth's rotational axis $\left(24.1^{\circ} ; 6,000\right.$ years ago and $23.4^{\circ}$ in present) and the eccentricity that has also been different during $\mathrm{MH}$ (present climate - 0.016724 and HM $\underline{0.018682)}$.

Focusing on the simulation of the MH climate, mainly those of PMIP I and II various studies have been performed. However, most of these studies were focused on North Hemisphere and they reported important changes on the Asia and the Africa monsoon system. For example: Jossaume et al. (1999) analyzed the MH climate using a set of 18models simulation and confirmed the increasing of the amplitude of the temperature $\underline{\text { seasonal cycle in North Hemisphere and its reduction in South Hemisphere. }}$

Poucas são as pesquisas de modelagem paleoclimática realizadas para o continente sulamericano. Isso se deve, principalmente, à distribuição esparsa dos dados oceânicos e terrestres, comparando-se ao Hemisfério Norte. Valdes (2000) é o pioneiro, que tem como foco de suas pesquisas o clima da América do Sul no HM. Ele analisou os resultados de 19 modelos do PMIP e verificou que, em geral, ocorre um resfriamento do continente Sul-americano durante o trimestre dezembro-janeiro-fevereiro (DJF) e um aquecimento em junho-julho-agosto (JJA), como esperado devido à variação dos parâmetros orbitais. Simulações utilizando o modelo global acoplado oceano-atmosfera, do Institut Pierre Simon Laplace da Universidade de Paris (IPSL), verificaram que a região nordeste do Brasil encontrava-se mais úmida e mais fria (principalmente no verão) e, em média, a estação seca era mais curta, durante o Holoceno Médio (Silva Dias et al. 2002). Liu et al. (2004) e Harrison et al. (2003) a partir de simulações com o Fast Ocean Atmosphere Model (FOAM) verificaram também, que a monção da América do Sul é enfraquecida, no MH principalmente pela redução da insolação no verão.

Com isso, é necessário que se avance na compreensão de como os modelos respondem a grandes mudanças, quer sejam natural ou antropogênica. Assim, um estudo do comportamento e da capacidade do modelo em simular as características de grande escala do MH, viabilizará o entendimento dos possíveis mecanismos responsáveis pela 
mudança do clima no passado, o que ajudará na compreensão das possíveis mudanças $\underline{\text { no clima do futuro. }}$

Paleoclimate indicators provide what can be considered as "observational" evidences of long term climate variations and change. These indicators are useful to detect changes in the climate regimes in the past and to understand the functioning of the climate system. In addition paleoclimate records are useful for the "validation" of the reconstructions of the past climate through models.

Climate models have provided simulations of the impacts of the orbital parameter variations on the simulation of the Mid Holocene (MH) climate (about 6,000 years ago, characterized by a natural climate change due to variation on the orbital parameters).

Paleoclimatic indicators suggest that significant changes in the solar forcing during the Holocene led to expressive changes on the climate resulting in changes in temperature, rain, sea level height, circulation and in the intensity and frequency of El Niño. High-resolution climate indicators suggest that during the Holocene the El Niño and perhaps other interannuat variability modes were impacted and readjusted by large-scale climate changes caused by the variation of the orbital parameters. Climate models have been used to simulate markable climate episoles, such as, the climate of Last Glacial Maximum (LGM) (Ganopolski et al., 1998), or the climate evolution during abrupt climate events (Manabe and Stouffer, 1997) to help understand the past climate change mechanisms. Global climate models (GCM) are perhaps the only way of testing the hypothesis, such as the Milankovich theory, which suggests that the glaciations have started due to changes on the orbital parameters, which caused a reduction of the solar radiation during the Northern Hemisphere summer (Khodri et al., 2001). The models allow for the establishment of a eause effect association that could have happened in the past. Also they help to fill the vacumm between at regional levels and to reconstruct the global paleoclimate because paleoclimatic indicators are very sparse over time and space. A quantitative understanding of such mechanisms is perhaps the best way of learning about the past or the future climate.

There are evidences of a positive climate feedback in the response of climate to changes in orbital parameters. Comparisons between models and between models and paleoclimate indicators data have been performed by the Paleoclimate Modelling Intercomparisen Project (PMIP) (Jossaume and Taylor, 1995). Although the simulations 
from the atmospheric climate models for the Medium Holocene produce an intensification of the monsoon systems as a response to the changes on the orbital parameters from 6,000 years ago, the models tend to underestimate the precipitation of the monsoon systems (Joussaume et al., 1999).

The MH climate represents a "good test" to assess the performance of a GCM in a elimate change mode, mainly because: (a) it is a relatively recent paleoclimate period marked by a natural climate change, and with mean sea surface temperature (SST) characteristics similar to the present; (b) due also to the existence of paleoclimate indicators relative to this period, which can be used to validate the model; and (c) to the possibility of comparing the results of this run with standard simulations of the MH, realized by several worldwide climate centers, using global climate models of PMIP I and II (Braconnot et al., 2000). In PMIP all the models have changed the orbitat parameters and reduced the carbon dioxide (CO2) concentration to $280 \mathrm{ppm}$. The SST is assumed as similar to present climate values, that is, a pre industrial atmosphere (Valdes, 2000). Analysis of oceanic sediments for the MH period shows that the ehanges of SST were small (Ruddiman and Mix, 1993 and Morley and Dworetzky, 1993). Therefore only the radiation forcing is believed to have a more remarkable contribution for the different climate of this period. These experiments used atmospheric and coupled ocean models (AGCM and AOGCM, respectively).

Several climate characteristics obtained through numerical experiments were captured by all the models, for both MH and LMG. These include the global cooling during LMG and the expansion of the monsoon in the Northern Hemisphere summer during MH. However, there are large differences in magnitude of circulation and rainfall among the several model results.

For the Southern Hemisphere, reconstrutions of the temperature in Antaretica during the Holocene show a warming between 11,000 and 9,000 years, followed by a graduat cooling during the late Holocene (Masson et al., 2000). This relatively warmer period ean not be explained by changes in insolation alone, but perhaps by the large scale reorganization of the latitudinal transport of heat through the oceans and the atmosphere. 
The use of AGCMs and AOGCMs allows for the simulation of the impacts of the anthropogenic changes in the atmospheric composition and land use (IPCC, 2001), as well as the impact of natural climate variability such as changes of the orbital parameters. The solar radiation available at the top of the atmosphere during MH was quite different of the present day values, due to changes of the orbital parameters. About 6,000 years ago, during the Northern Hemisphere summer (about August), the Earth was closer to the Sun (perihelion) than it is in the present times. As a result the insolation seasonal cycle was modified. Thus, during MH the peak of insolation in the tropics occurred in August whereas the minimum occurred in February. In North Hemisphere this change intensified the seasonal cycle of the insolation (Liu et al., 2004). The change in the insolation is not exactly symmetric about the equator, due to both the inclination of the Earth's rotational axis $(24.10 ; 6,000$ years ago and 23.40 in present) and the eccentricity that has also been different during MH (present climate0.016724 and $\mathrm{HM} \quad 0.018682)$.

Several studies using the CPTEC's AGCM have been done to testing the ability of the model in simulating the atmospheric characteristics and their variability in interanual and decadal seales for present climate (Cavaleantict al. 2002; Marengo et al. 2003 and Marengo 2005). However, CPTEC's model has not been used for paleoclimate simulations or future climate change scenarios yet.

Focusing on the simulation of the MH climate, mainly those of PMIP I and II various studies have been performed. However, most of these studies were focused on North Hemisphere and they reported important changes on the Asia and the Africa monsoon system. For example: Jossaume et al. (1999) analyzed the MH climate using a set of 18 models simulation and confirmed the increasing of the amplitude of the temperature seasonal cycle in North Hemisphere and its reduction in South Hemisphere. All the models reproduced the increasing of the precipitation of the Asia and Africa monsoon, highlighted by a northward expansion of the precipitation zone. However, all the models underestimated the intensity of the north Africa monsoon. Gagan et al. (1998) observed that the tropical ocean was warmer (SST anomaly $>+1^{\ominus}-\mathrm{C}$ ) during MH and colder (SST 
anomaly $<2^{\ominus}-$ C) during LGM. Analyzing other indicators, they concluded that the elimate was warmer between $7,000-4,000$ years ago.

Paleoenvironmental studies using paleoclimate indicators have been conducted for several regions of South America and have provided an approximated representation of the past climate. These studies revealed a drier behavior during the MH over both the Amazon region (Tureq et al., 1998; Behling et al., 2000; Tureq et al., 2002) and south and southeast Brazil (Behling, 2001; Tureq et al., 2002). Northern South America, including Northeast Brazil exhibited a southward displacement of the ITCZ during the MH compared with present day (Mayle et al. 2000, and Haug et al. 2001). These results are in agreement with results from simulations by Silva Dias et al. (2002) that, using the Institut Pierre Simon Laplace (IPSL) of the University of Paris AOGCM have verified that Northeast Brazil was wetter and colder (especially during austral summer) and, in average, the dry seasen was shorter during the MH. Keefer et al. (2003) analyzed paleoclimate data from the south coast of Peru and verified that several events of El Niño occurred during all the Plestiocene and during two or three Holocene divisions, with significantly different frequencies.

However, the period of greater intensity of El Niño during Holocene was that between 11,000 and 9,000 years ago. During the MH, only four severe El Niño events were registered since, according with the paleoclimate records the El Niño events during the MH were relatively weak. These conditions have also been verified by Fontugne et al. (1999), which analyzed paleoclimate records from Quebrada de los Burros, in southern Peru (State of Tacna). This data suggest low intensity and frequency of occurrence of El Niño during the MH. Thempson (1995) verified, through analysis of ice cores, that this region of Peru between 8,200 and 5,200 years ago was warmer than in present day. Sifeddine et al. (2003) analyzing lake data from Northeast Brazil (2.96 S and $\left.43.41^{\circ} \mathrm{W}\right)$ 
verified a lowering of the level of the lake, between 11,000 and 4,500 years age, suggesting a drier period in comparison with present climate. These results confirm those found by Ledru et al. (2002) using pollen data.

Data from Antarctica and Greenland showed a global decrease in atmospheric temperature during MH (Steig, 1997), while north Atlantic SST warmed and the Tropical Pacific and Antarctic SSTs cooled (Gagan et al., 1998) creating a dipole between northern and southern hemisphere (Pessenda et al., 2004).

Therefore, the $\mathrm{MH}$ is well known as a period of particularly important changes in elimate. The focus on the $\mathrm{MH}$ is due both to the remarkable climate conditions of this period, for which the main forcing is well known a mainly from natural causes (change in the orbital parameters), and also due to a relative abundance of paleoclimate records for the period. In this context, the current study analyses the behavior and of the ability of the CPTEC AGCM in simulating the large-scale characteristics of $\mathrm{MH}$, with the goal of enabling us to an understanding the possible mechanisms responsible for the climate change in this past period, which certainly would provide new insights in the comprehension of possible changes and feedbacks for future climates.

The main objective of this paper is to analyze the climate variations, no que diz respeito principalmente a precipitação e temperature, -in South America during the $\mathrm{MH}$, using the CPTEC's T062L28 model. In section 2 we describe the datasets and the simulations the present and the $\mathrm{MH}$ climate; in section 3 contains the comparison between present and the MH climate caused by the changes in the orbital parameters. Simulations are compared to paleoenvironmental records in order to determine whether the simulations are consistent with observation. Finally our discussions are summarized and in section 4 are conclusions. 


\section{MATERIALS AND METHODS}

Two sets of 40-years simulations were produced (as shown in Table 1). The three first years of integration were considered as part of the model's spin-up and were put aside at the analysis. In both experiments we used the climatologic AMIP SST (1956 to 2003) and the National Centers for Environmental Prediction/National Center for Atmospheric Research (NCEP/NCAR) reanalysis as boundary and initial conditions, respectively. The use of this data set is justified due to the fact that the MH was not characterized either by glaciation or very warm conditions but because it was a period marked by average climate characteristics similar to the present climate (Seppã et al., 2005). The $\mathrm{CO}_{2}$ concentration and the orbital parameters corresponding to the $\mathrm{MH}$ period were calculated according to Berger (1978), and are described in Table 1 and Table 2, respectively. The concentration of $\mathrm{CO}_{2}$ for the $\mathrm{MH}$ was $280 \mathrm{ppm}$. This value refers to the pre-industrial period and is the same used in the PMIP pattern-simulations and was verified by Petit et al. (1999), who analyzed an ice core from Vostok, which dated 420.000 years ago. They verified that the largest variations (180 ppm and 280-300 ppm) of $\mathrm{CO}_{2}$ were associated with glacial and interglacial transitions.

\section{Table 1}

Table 2

\section{CPTEC Atmospheric General Circulation Model}

In this paper we use the CPTEC's AGCM, that for the first time was run and tested in experiments of paleoclimate simulations. The model is run with a T062L28 resolution. The horizontal resolution is about the same, about $200 \mathrm{~km}$ lat-lon. The AGCM uses a surface scheme the simple Simplified Biosphere Model ( $\mathrm{SSiB}$ ) that considers the influence of the vegetation from a more sophisticated viewpoint (Xue et al., 1991). The parameterizations used on the model are: radiation of short wave, according to Lacis 
and Hansen (1974), and modified by Ramaswamy and Freidenreinch (1992); radiation of long wave by Harshvardhan et al. (1987); deep convection of the Kuo (1974) type; shallow convection, according to Tiedtke (1983) (Cavalcanti, 2002). More details on this models it is skill in simulating South American climate can be found in Marengo et al. (2003). Several studies using the CPTEC's AGCM have been done to testing the ability of the model in simulating the atmospheric characteristics and their variability in interanual and decadal scales for present climate (Cavalcanti et al. 2002; Marengo et al. 2003 and Marengo 2005). Verificaram que o MCGA tem destreza em simular as principais características do clima global. As zonas de convergência no Hemisfério Sul são simuladas razoavelmente bem, apesar de a precipitação ser superestimada na parte sul e subestimada na parte norte desses sistemas. Regionalmente, no entanto, há erros sistemáticos, a precipitação é subestimada em algumas áreas do interior do continente incluindo a bacia Amazônica, e superestimada sobre os Andes e Nordeste brasileiro. Apesar desses erros o modelo consegue representar bem a variabilidade interanual do Nordeste e da Amazônia. However, CPTEC's model has not been used for paleoclimate $\underline{\text { simulations or future climate change scenarios yet. }}$

The present-day value of $\mathrm{CO}_{2}$ concentration used in the model is $345 \mathrm{ppm}$. However, this $\mathrm{CO}_{2}$ value is stable and smaller than the carbon dioxide concentration in present time (about $370 \mathrm{ppm}$ ). Nevertheless we will keep the value of $345 \mathrm{ppm}$, for comparisons with other simulations realized by PMIP that use this value.

Two sets of simulations were performed: present climate (PC) and Mid Holocene (MHS1). The MHS1 simulation represents a set of 40 years simulation where the $\mathrm{CO}_{2}$ concentration and the orbital parameters corresponding to the $\mathrm{MH}$ period. We analyzed and compared the annual cycles of short-wave radiation (SW), temperature, precipitation, sea-level pressure, long-wave radiation and atmospheric low-level circulation, to verify the large-scale patterns associated with the atmospheric circulation during the $\mathrm{MH}$ and the present climate. All the analyses are focused over South America. Differences between climates between for the MHS1 simulation are discussed 
with the simulations produced by the PMIP models for the same period using different AGCMs (Jossaume and Taylor, 1995; Valdes, 2000, among others). This is done to analyze how the different models capture the climate change due to the variations in the insolation seasonal cycle, caused by the changes in the orbital parameters. Finally, the results are compared to paleoenvironmental studies in order to validate the CPTEC's AGCM (Table 3).

\section{Table 3}

\section{RESULTS AND DISCUSSIONS}

Figure 1 shows the difference between the MH period and present day annual cycle of the SW that reaches the top of the atmosphere. It is verified that during the $\mathrm{MH}$ the amount of radiation at the top of the atmosphere was different from present climate, due to the change in the orbital parameters. In the winter of the Southern Hemisphere, the Earth planet was closer to Sun during the $\mathrm{MH}$, exactly the opposite from the present. As a result, more SW reached Earth between April and September and less between October and March, between $0^{\circ}$ and $30^{\circ} \mathrm{S}$, thus reducing the insolation seasonal cycle in the Southern Hemisphere tropics. This is in agreement with the results by Valdes (2000). Another maximum of insolation during the MH can also be verified in the spring between $30^{\circ} \mathrm{S}$ and $90^{\circ} \mathrm{S}$, in agreement with Braconnot et al. (2000). In South Hemisphere, between December and February (DJF), the average insolation showed a decreasing of $19.0 \mathrm{Wm}^{-2}$, during the $\mathrm{MH}$. This is equivalent to a reduction of $4.8 \%$ in comparison with present-day insolation (Vettoretti, et al. 1998).

\section{Figure 1}

Figure 2 shows the seasonal average precipitation during the $\mathrm{MH}$ and the difference of the seasonal average precipitation simulated during the $\mathrm{MH}$ and present day (MHS1PC), for the four seasons. The general picture is that Northeast Brazil was wetter (by 
about 10\%) 6,000 years ago during the $\mathrm{MH}$. This is in agreement with the latent heat flux distribution (not shown) that during the whole year increased about $20 \%$, mainly in the east bound of Northeast Brazil. This is confirmed by the paleoenvironmental studies by Mayle et al. (2000), Haug et al. (2001), and Pessenda et al (2005). However, in autumn all the coast of northern South America and central Northeast Brazil were found drier (by about 5\%).

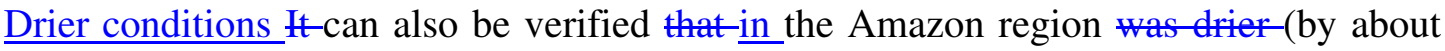
$10 \%$ ) in the MHS1 simulation, as compared to present, and in agreement with paleoclimate evidences (Turcq et al., 1998; Behling et al., 2000; Turcq et al., 2002). Autumn and spring are exceptions to this picture for which Northwest Amazonia exhibited higher precipitation in the MHS1 simulation, that can be due to the north of ITCZ displacement. -Southern Brazil was drier in the MHS1 simulation, except during summer and autumn, for which the results of the simulations suggest that the eastern band of south and southeast regions were wetter. This reduction of the precipitation can be due to the weakening of the low level northerly flow east of the Andes coming from the Amazon region, (to be discussed in the next section), and suggesting a reduced the transport of moisture from the Amazon basin into southeastern South America during the MH during summer. On this season, what is also detected during the $\mathrm{MH}$ is the northwesterly flow coming from the subtropical Atlantic high, that in the MH was more intense and closer to the continent, similar to what is observed in present climates during the autumn and winter seasons. As a consequence, all these changes influence Therefore the formation and positioning of the South Atlantic Convergence Zone (SACZ), were influenced eausing due a reduction of the precipitation in the SACZ $\underline{\text { in }}$ this region as compared to the present. The results agree with Valdes (2000) in a simulation of the MH with 19 AGCMs. Wetter conditions can also be verified in the 
Argentina and Chile, except in the south region. The Bolivia and Peru were drier in the MHS1 simulation, except during winter and spring. There is tendency for a weakening of the SACCAZ in the MHS1, associated with a reduction in the intensity of the Bolivian high (see next section) and the increase of the low level northerly flow east of Andes in the austral summer in latitudes south of $20^{\circ} \mathrm{S}$, without Amazonian influence. This pattern of the weakening/intensification of the LLJ/SACZ are also observed in present climates during summer. However, in the MH this alternate pattern between SACZ/LLJ (definir LLJ) does not involve moisture transport from Amazonia but from the subtropical Atlantic, consequence of the intensification and closer position of the SASH in relation to the continent during austral. These precipitations characteristics can be confirmed from the field of outgoing long wave radiation (LW) (not shown) that shows low values in regions of maximum precipitation as it is the case of ITCZ, SACZ and the convective activity in the Amazon region. The difference field of the long wave radiation between the MHS1 and the PC experiments suggests an increasing of the LW through South America as a whole. However, this increasing of the LW can be attributed to the increasing of the cloudiness (may be high level clouds) alone and not necessarily with an increasing of convective precipitation.

Figure 2

Figure 3 illustrates the seasonal average temperature fields during the $\mathrm{MH}$ (simulation MHS1) and the difference of temperature between MHS1 and PC, for the four seasons. The difference field between the seasonal average temperature of the MHS1 and PC simulations suggests that South America were colder (negative anomalies up to $3^{\circ} \mathrm{C}$ ) in agreement with the results of Steig $(1997,1999)$. The exception is the Amazon region that was found warmer (by about $3^{\circ} \mathrm{C}$ ), while Northeast Brazil was colder (by about $\left.3^{\circ} \mathrm{C}\right)$ all year along, in agreement with Valdes (2000). In a general, Figure 3 suggests 
that during the MH South America was colder (by about $3^{\circ} \mathrm{C}$ ), in the MHS1 experiment, in agreement with Steig (1997).

Figure 3

Figure 4 shows the difference of the low-level wind $(850 \mathrm{hPa})$ between the MHS1 and the PC simulations. It is detected an increase in the intensity of the average flux at 850 hPa over the Southeastern coast of South America during the MH. This is more remarkable in summer and autumn, and is mainly a consequence of a South-Atlantic subtropical high (SASH) more intense and closer to the continent. This pattern during summer in the $\mathrm{MH}$ is similar to that detected in autumn and winter during the PC. Hence, some significant changes can be observed, such as: (a) an enhancement of the low level circulation of the SASH, (b)-a intensification of the flow east of Andes south of $20^{\circ} \mathrm{S}$ (what suggests a possible influence in the intensity of the circulation of the low level jet - LLJ, mainly in the summer and due to an enhancement of the low-level circulation of the SASH(a); (eb) a weakening of the northeasterly trade winds, that explains the northward shift of the ITCZ and a possible reduction of moisture transport from Amazonia into southeastern South America as observed in the MHS1 experiment, (Ac) a decreasing of the low-level convergence over the Amazon region, that explains the reduction of the precipitation in this region during the $\mathrm{MH}$. It has also detected a change of signal of the wind between summer (northeasterly flow) and winter (southeasterly flow) over the Amazon regionregion that characterizes monsoon-like circulation.

In present climates, the autumn and winter pattern shows a LLJ flux coming from the subtropical South Atlantic that is closer to the continent at this tieme of the year. Even though the stronger winds of these LLJs, the moisture content is lower than the moisture content from the air masses transported by the trade winds during summer (Marengo et 
al. 2004). The SACZ is weaker or absent in those seasons in present times Making an analogy with the $\mathrm{MH}$, the summertime circulation in that period shows a reduction of the Amazonian flow and possibly more cold fronts entering in lower latitudes, contributes to a reduction of the precipitation in the region where SACZ is positioned in present day.

In upper levels (Figure 5), the winter circulation regime over South America tends to be more zonal, whereas in the summer the flow is weaker and more meridional, especially near to the east and west coasts of the South America. In the summer the Bolivian high and the upper level trough over Northeast Brazil is detected in the HMS1 experiment. Studies with atmospheric models show that the Bolivian high is related with the release of latent heat of the deep convection on the Amazon region (Gill, 1980), and as if it observes during the summer has the precipitation maximum on this region (Figure 2) in both the present and the MH. In the autumn, the precipitation maximum, related to the Bolivian high is found in the southwest of the Amazonia only in the MHS1 simulation. Comparing the simulations of MHS1 and PC, the upper-levels trough was more intense and the Bolivian high slightly weakened on the austral summer in the MHS1 experiment. This suggests that the lower and upper level circulation field in SouthAmerica depict a monsoon system during austral summer, even though a bit weaker that in the present. This weakening was reflected in the desintensification of the SACZ and the weakening of the Bolivian high, with a reduction of the precipitation in the South America, except in the northeast region of Brazil, where the precipitation slight increase is an indication of the retreat of the monsoon precipitation from central Amazon towards the coast of Northeast Brazil.

\section{Figure 4}


Figure 6 shows the difference of the seasonally averaged integrated moisture flux from surface to the 300-hPa level, between the MHS1 and PC simulations for all the seasons. The main characteristic is that the moisture transport from ocean to continent is increased during the MH, mainly in Southern South America coast. On the other hand, It-can also be observed that the moisture transport from the tropical Atlantic into the Amazon region has decreased primarily in autumn. This explains the reduction of the precipitation in this region. The moisture transport from the Amazon region to central and southeast Brazil was also smaller during the MH during austral summer, what might have influenced both the positioning and the intensity of the SACZ 6.000 years ago.

In winter, the MHS1 simulation shows an increase in the southerly moisture flux over west central Brazil, which could be explained by frontal penetrations, as it happens during summer time present climate. This causes an increase of precipitation in that region during the $\mathrm{MH}$

\section{Figure 6}

Figure 7 illustrates the seasonal mean sea-level pressure for the MHS1 experiment, and the difference between the MHS1 and the PC experiments, for all the seasons. In the MHS1 experiment, the mean sea level pressure is very similar to present day climate, with regions of low pressure near the poles, high-pressure areas in the subtropics and the low pressure belt in the equatorial band, as observed in the present in both hemispheres. The differences between the MHS1 and PC simulations are subtle. In general, the result suggests a reduced intensity of the South Pacific subtropical high (SPSH) and slight intensification of the SASH all-over the year, except for the austral spring when both those pressure centers tend to intensify, in addition to an 
intensification of the Chaco Thermal low. That can explain the increasing of the precipitation northwest of Argentina and Chile for this period.

The simulations for MHS1 and PC were performed using the same boundary conditions, just changing the radiative forcing and the $\mathrm{CO}_{2}$ concentration. This determines that there were not large variations in the pressure and temperature gradients between ocean and continents. However, during the MH more energy was available at the equator and less at the poles (Figure 1), increasing the meridional temperature gradient. In an attempt to be establish a thermodynamic equilibrium, the Hadley Cell (not shown) was accelerated in its descending branch, around $30^{\circ} \mathrm{S}$, determining the intensification of the South Atlantic Subtropical High (SASH). This intensification tends to enhance the LLJ south of $20^{\circ} \mathrm{S}$ bringing moisture from the subtropical South Atlantic into southeastern South America, and possibly weakening the $\mathrm{SACZ}$, because. $\mathrm{T}$ this air mass is not as much humid as that coming from Amazonia during summertime in present climates, reducing the rainfall rates in southeastern Brazil.

The increase in the pole-equator thermal gradient also determines an increase in the transients due to an intensification of the wind shear. The $850 \mathrm{hPa}$ circulation difference field (Figure 4) exhibits a trough in south central Argentina that is intensified during the MH. Thises could determine an increase in the frequency of perturbations during this period. By comparing the temperature (Figure 3) and moisture flux (Figure 6) it is verified that cold fronts during the $\mathrm{MH}$ in winter brought cold and moister air masses from the south in the $\mathrm{MH}$, as compared to PC.

Rainfall in Amazônia during the MH was reduced mainly in the northwestern section due to the weakening of the trades (Figure 4), while southern Amazônia was somewhat wetter due to the effect of the air masses coming from the subtropical South Atlantic, with a SASH more intense and closer to the continent. 


\section{Figure 7}

In order to assess whether the CPTEC's AGCM captures the regional "observed" characteristics of the $\mathrm{MH}$ as suggested by paleoenvironmental studies (Turcq et al. 1998; Behling et al. 2000; 2001; Mayle et al. 2000; Haug et al. 2001; Turcq et al. 2002; de Oliveira et al. 1999 and Sifeddine et al. 2001), the annual cycles of precipitation and temperature modeled for $\mathrm{MH}$ are analyzed. We focused on Amazon and Northeast Brazil, and central-west and southeast Brazil (Figures 7 and 8, respectively).

The basic difference between the MHS1 and PC simulations is the anticipation of the onset of the rainy season (not shown). This can be explained through the difference in the distribution of the short wave radiation, that decreased the intensity of the $\mathrm{MH}$ seasonal cycle; the northward shift of the ITCZ in the MHS1 experiment; and also due to the AGCM do not properly simulate the SACZ for MHS1, perhaps by the stronger of the northerly flow east of Andes south of $20^{\circ} \mathrm{S}$, that underestimates the moisture transport for the SACZ region. From the analyses of the PC and MHS1 simulations, it is detected an increase of the precipitation in Amazonia in the four seasons, except for some specific months. A more detailed analysis of the average seasonal annual cycle of precipitation shows a wetter Amazonia (region in the box $0^{\circ}-10^{\circ} \mathrm{S}$ and $50^{\circ} \mathrm{W}-70^{\circ} \mathrm{W}$ ) in the MHS1 simulation, except for the months of January, February and June (Figure 8). Northeast (region in the box $01^{\circ} \mathrm{S}-20^{\circ} \mathrm{S}$ and $48^{\circ} \mathrm{W}-35^{\circ} \mathrm{W}$ ) Brazil was wetter in the MHS1 experiment, except for April, in agreement with paleoenvironmental studies (Mayle et al., 2000 and Haug et al., 2001). Central-west (region in the box $20^{\circ} \mathrm{S}-10^{\circ} \mathrm{S}$ and $60^{\circ} \mathrm{W}-50^{\circ} \mathrm{W}$ ) Brazil in the MHS1 experiment is wetter, except for May, June and October, and also wetter in the southeast (region in the box $25^{\circ} \mathrm{S}-15^{\circ} \mathrm{S}$ and $53^{\circ} \mathrm{W}-40^{\circ} \mathrm{W}$ ) region, except for June, August and September. 
There are not noticeable differences in the field of the temperature (Figure 9) between the experiments PC and MHS1 simulations, in agreement with Figure 3.

\section{Figure 8}

Figure 9

\section{CONCLUSIONS}

Changes in the orbital parameters of Earth (namely: eccentricity, obliquity and precession) during the $\mathrm{MH}$ period modified the seasonal cycle of insolation in both hemispheres. During the MH in the southern hemisphere it was detected an attenuation of the seasonal cycle whereas an intensification occurred in the Northern Hemisphere. Comparing the results of the simulations from CPTEC's T062L28 AGCM to paleoclimate indicators and paleoclimate simulations resulting from the PMIP models, it is concluded that the CPTEC's AGCM is able to simulate the main large-scale climate patterns for the MH period. The climate simulations of the Mid Holocene suggest that Northeast Brazil was colder and wetter, and the south and southeast Brazil were drier as compared to the present, in agreement with previous results by Valdes (2000).

An increase of the intensity of the mean seasonal flow at the $850-\mathrm{hPa}$ level south of $20^{\circ} \mathrm{S}$ was detected over the continent during $\mathrm{MH}$. This occurs especially in summer and in autumn, and is mainly a consequence of an intensified and closer to the continent South-Atlantic subtropical high (SASH) due the Hadley Cell was accelerated in its descending branch, around $30^{\circ} \mathrm{S}$, consequence of the increase the meridional temperature gradient. North of $20^{\circ} \mathrm{S}$ the moisture coming from Amazonia was weaker than in the present. Therefore, some important changes can be observed: (a) the increase of the intensity of the circulation of the South Atlantic subtropical high; (b) the intensification of the of the northerly flow east of Andes south of $20^{\circ} \mathrm{S}$ (c) the decreasing in the moisture transport from the Amazon basin to central and southeast 
Brazil, which can influence the formation and intensity of the SACZ; (e) the reduced intensity of the northeasterly trade winds north of $20^{\circ} \mathrm{S}$, what can explain the northward positioning of the ITCZ, and (f) the weakening of the low-level convergence over the Amazon region, what can explain the reduction of the precipitation in this region during the $\mathrm{MH}$.

It has also been observed a change of the wind pattern between summer and winter over the Amazon region. This suggests that the monsoon circulation of South America has also existed in the MH period, even though was slightly weaker due to the desintensification of the LLJ coming from Amazonia, a desintensification of the Bolivian high, and the SACZ and the reduction of the precipitation in southeastern and west central Brazil. In general, our results agree with those from the PMIP simulations and with the paleoenvironmental evidences.

In the temperature fields it has been observed that in general, the CPTEC's model simulated a cooling during the $\mathrm{MH}$ period, up to $3^{\circ} \mathrm{C}$ in the MHS1 experiment. This can be due to the reduction of the $\mathrm{CO}_{2}$ concentration, from $340 \mathrm{ppm}$ to $280 \mathrm{ppm}$ and agrees with the paleoclimate indications by Steig (1997).

The results suggest that CPTEC's AGCM has captured, from a general stand point, the large-scale patterns of the atmosphere for a recent geological period, marked by a natural climate change, as it was the case of $\mathrm{MH}$.

\section{ACKNOWLEDGMENTS}

This work is part of the first author's doctoral thesis at the Meteorology Graduate Program of the Brazilian Institute of Space Research (INPE), under the supervision of the second author. 
The first author was funded by a pos graduate grant from the Brazilian Coordenação de Aperfeiçoamento de Pessoal de Nível Superior - CAPES, and Jose Marengo was funded by the Conselho Nacional de Desenvolvimento Científico e Tecnológico CNPq. Additional thanks are due to Bruno Turcq, IRD CNPq Paleotropica Project and Laboratoire Mixte Franco-Brésilien De Recherches Environnementales - Lamiré, to Pascale Braconnot to facilitate and providing access to paleoclimatic indicators data banks and to the results from simulations from the IPSL coupled model. Thanks also are due to Drs. Pedro Leite Silva Dias and Enio Pereira de Souza for their comments and suggestions.

\section{REFERENCES}

Behling, H.; Negret, A. J.; Hooghiemstra, H. Holocene Amazon rainforest-savanna dynamics and climatic implications: high-resolution pollen record from Laguna Loma Linda in eastern Colombia. Journal of Quaternary Science, v. 15, n. 7, p. 687-695, 2000.

Behling, H. South and southeast Brazilian grasslands during Late Quaternary times: a synthesis. Palaeogeography, Palaeoclimatology, Palaeoecology, v. 2710, p. 1-9, 2001. Berger, A. L. Notes and Correspondence: Long-Term Variations of Daily Insolation and Quaternary Climatic Changes. Journal of Atmospheric Science. 35, 2362-2367. 1978

Braconnot P, Joussaume S, DE Noblet N, Ramstein G., 2000: Mid-holocene and Last Glacial Maximum African monsoon changes as simulated within the Paleoclimate Modelling Intercomparison Project. Global and Planetary Change 26: (1-3) 51-66.

Cavalcanti, I. F. A. et al., Global Climatological Features in a Simulation Using the CPTEC-COLA AGCM. Journal of Climate. 15, 21, 2965-2988. 2002. 
Davies, R. Documentation of the solar radiation parameterization in the GLAS climate model. NASA Tech Memo. 83961, 57 pp. 1982.

Fontugne, M. Usselmann, P. Lavallèe, D. Julien, M. And Hattè, C. El Nino Variability in the Coastal Desert of Southern Peru during the Mid-Holocene. Quaternary Research. V. 52, n. 2, pp. 171-179. 1999.

Gagan, M.K., Ayliffe L.K., Hopley, D., Cali, J.A Mortimer,G. E., Chappell,J., Mcculloch, M. T., and Head, M. J. Temperature and surface-ocean water balance of the mid-Holocene tropical western Pacific. Science, v. 279, p. 1014-1017, 1998.

Ganopolski, A., C. Kubatzki, M. Claussen, V. Brovkin, and V. Petoukhov, The influence of vegetation-atmosphere-ocean interaction on climate during the midHolocene, Science, V280(N5371), 1916- 1919, 1998.

Gill, A. E., 1980: Some simple solutions for heat tropical circulation. Quart. J. Roy. Meteor. Soc., 106, 447-462.

Harshvardhan, K. M., Bromwich, D. H. and Corsett, T. G. A fast radiation parameterization for general circulation models. Journal Geophysical Research, 92, 1009-1016. 1987.

Haug, G. H.; Hughen, K. A.; Sigman, D. M.; Peterson, L. C.; Röhl, U. Southward Migration of the Intertropical Convergence Zone Through the Holocene. Science, v. 293, p. 1304--1308, 2001.

INTERGOVERNMENTAL PANEL ON CLIMATE CHANGE IPCC. Climate Change 2001: the scientific basis IPCC WG I TAR. Cambridge: Cambridge Univ. Press. p.881, 2001.

Jossaume, S. and Taylor, K. E. Status of the paleoclimate Modeling Intercomparison Project. In Proceedings of the First International AMIP Scientifc Conference, WCRP (World Climate Researche Programme) - 92. Moterey; 425 - 430. 1995. 
Joussaume S, Taylor KE, Braconnot P, et al. , 1999: Monsoon changes for 6000 years ago: Results of 18 simulations from the Paleoclimate Modeling Intercomparison Project (PMIP). GEOPHYS RES LETT 26: (7) 859-862.

Keefer, D. K, Moseley, M. E. AND deFrance S.D. a 38000-year record of floods and debris flows in the Ilo region of the Southern Peru and its relation to El Nino events and great earthquakes. Paleogeography, Paleoclimatology, Paleoecology. V.194, n.1, pp. 41-77. 2003.

Khodri M, Leclainche Y, Ramstein G, Braconnot P, Marti O, Cortijo E. Simulating the Amplification of Orbital Forcing by Ocean Feedbacks in the Last Glaciation. Nature. 410(6828):570-574. 2001

Kuo, H. L. Further studies of the parameterization of the influence of cumulus convection on large-scale flow. J. Atmospheric Science, 31, 1232-1240, 1974.

Lacis, A. A. and Hansen, J. E. A parameterization of the absorption of the solar radiation in the earth's atmosphere. Journal of the Atmospheric Sciences, 31, 118-133. 1974.

Ledru, M.P., Mourguiart, P., Ceccantini, G., Turcq, B. and Sifeddine, A. 2002: Tropical climates in the game of two hemispheres revealed by abrupt climatic change. Geology $30,275-78$.

Liu, Z, Harrison, S.P., Kutzbach, J. and Otto-Bliesner, B. Global monsoons in the midHolocene and oceanic feedback. Climate Dynamics. p. 157-182.2004.

Manabe, S and Stoufer, R. J.Coupled ocean-atmosphere model response to freshwater input: comparision to Younger Dryas event, Paleocenography, 12, 321-336. 1997.

Marengo, J. A. Mudanças Climáticas Globais e Regionais: Avaliação do Clima Atual do Brasil e Projeções de Cenários Climáticos do Futuro. Revista Brasileira de Meteorologia, v. 16, p 01-18, 2001. 
Marengo, J. A., et al., Assessment of regional seasonal rainfall predictability using the CPTEC-COLA atmospheric GCM. Climate Dynamics. 21, 459 - 475. 2003.

Marengo, J. A., Saulo, C., Nicolini, M. Climatology of the Low-Level Jet of the Andes as Derived from the NCEP-NCAR Reanalyses: Characteristics and Temporal Variability. Journal of Climate (2004). v. 17 (12): 2261-2279.

Marengo, J. A. Characteristics and spatio-temporal variability of the Amazon river basin water budget. Climate Dynamics (2005) 24: 11-22.

Masson V, Vimeux F, Jouzel J, et al. Holocene climate variability in Antarctica based on 11 ice-core isotopic records. Quaternary Research, 54 (3): 348-358. 2000.

Mayle, F. E.; Burbridge, R.; Killeen, T. J. Millenial-Scale Dynamics of Southern Amazonian Rain Forests. Science, v. 290, p. 2291--2294, 2000.

Morley, J. J. and Dworetzky, B. A. Holocene temeprature patterns and the South Atlantic, Southern and Pacific oceans. Global Climates since the Last Glacial Maximun, H. E. Wright et al., Eds., University of Minnesota Press, 125-135. 1993.

Pessenda, L.C.R., Gomes, B.M., Aravena, R., Ribeiro, A.S., Boulet, R. and Gouveia, S.E.M: The carbon isotope record in soils along a forest-cerrado ecosystem transect: implications for vegetation changes in the Rondonia State, southwestern Brazilian Amazon region. The Holocene 8, 631-35. 1998c

Pessenda, L.C.R., Gouveia, S.E.M., Aravena, R., Boulet, R. and Valencia, E.P.E. Holocene fire and vegetation changes in southeastern Brazil as deduced from fossil charcoal and soil carbon isotopes. Quaternary International 114, 35-43. 2004a.

Petit, J. R.; Jouzel, J.; Raynaud, D.; et al.. Climate and atmospheric history of the past 420,000 years from the Vostok ice core, Antartica. Nature. 399, p. 429-436, 1999. 
Ruddiman, W. F. and Mix, A. C. The North and equatorial Atlantic at 9000 and 6000 years B.P. Global Climates since the Last Glacial Maximun, H. E. Wright et al., Eds., University of Minnesota Press, 94-124. 1993.

Sandweiss, D. H.; Richardson, J. B.; Reitz, E. J.; Rollins, H. B.; Maasch, K. A. Geoarcheological Evindence from Peru a 5000 Years B.P. Onset of El Niño. Science, v. 273, p. 1531--1533, 1996.

Seppã, H., Hammarlund, D. and Antonsson, K. Low-frequency changes in temperature and effetive humidity during the Holocene in south-central Sweden: implications for atmospheric and oceanic forcings of climate. Climate Dynamics. 25, 285-297. 2005.

Sifeddine, A., Martin, L., Turcq, B., Volkmer-Ribeiro, C., Soubiis, F., Cordeiro, R.C. and Suguio, K. Variations of the Amazon rainforest environment: a sedimentological record covering 30,000 years. Palaeogeography, Palaeoclimatology, Palaeoecology. v $168,221-35.2001$.

Sifeddine, A., Albuquerque, A.L.S., Ledru, M.P., Turcq, B.,Knoppers, B., Martin, L., de Mello, W.Z., Passenau, H, Dominguez, J.M.L., Cordeiro, R.C., Abrao, J.J. AND Bittencourt, A.C.D.P. A 21000 cal years paleoclimatic record from Caco Lake, northern Brazil: evidence from sedimentary and pollen analyses. Palaeogeography, Palaeoclimatology, Palaeoecology 189, 25-34. 2003

Steig, E.J.: Mid-Holocene climate change. Science 286, 1485-87. 1999

Steig, E.J., Hart, C.P., White, J.W.C., Cunningham, W.L., Davis, M.D. and Thompson, L.G., Mosley-Thompson, E., Davis, M.E., Lin, P.-N. Henderson, K.A., Cole-Dai, J., Bolzan, J.F. and Liu, K.-B: Late glacial stage and Holocene tropical ice core records from Huascaran, Peru. Science 269, 46-50. 1995 
Silva Dias, P. L.; Silva DIas, M. A.; Braconnot, P.; Turc, B. Evaluation of Model Simulation of 6k and Present Climate in South America. In: Congresso Brasileiro de Meteorologia, 12., 2002. . Foz do Iguaçu. Anais. São Paulo: USP, 2002.

Thompson, E., Davis, M.E., Lin, P.-N., Henderson, K.A., Cole-Dai, J., Bolzan, J.F. and Liu, K.-B. 1995: Late glacial stage and Holocene tropical ice core records from Huascaran, Peru. Science 269, 46-50.

Tiedtke, M., 1983: The sensitivity of the time-mean large-scale flow to cumulus convection in the ECMWF model. Pro. Workshop on convection in large-Scale Numerical Models, Reading, United Kingdom, ECMWF, 297-316.

Turcq, B.; Sifeddine, A.; Martin, L.; Absy, M. L.; Soubies, F.; Suguio, K.; VolkmerRibeiro, C. Amazonia rainforest fires: A lacustre record of 7000 years. Ambio, v. 27, n. 2, 139-142, 1998.

Turcq, B.; Albuquerque, A L. S., Cordeiro, R. C., et al. Accumulation of organic carbon in five Brazilian lakes during the Holocene. Sedimentary Geology, v. 148, 319-342, 2002.

Valdes, P. J. South American paleoclimate model simulations: how reliable are the models? Journal of Quaternary Science, v. 15, n. 4, p. 357-368, 2000.

Vettoretti, G. Peltier, W. R. and McFarlane, N. A. Simulations of Mid-Holocene Using an Atmospheric General Circulation Model. Journal of Climate, v. 11, n. 10, p. 2607$2627,1998$.

Xue, Y., Sellers, P. J., Kinter, J. L. and Shukla, J. A Simplified Biosphere Model for global climate studies. Journal of Climate, 4, 345-364. 1991. 